\title{
缶用鋼板の表面解析亡製品特性
}

\author{
市 田 敏 郎*
}

\section{Surface Analysis and Characterization of Steel Sheets for Cans}

Toshio ICHIDA*

\section{1. ま え がき}

缶詰は, 19世紀はじめ, 数10万の軍隊を率いてョーロ ッパ大陸を縦横無尽に駆けめぐっていたナポレオンの求 めに応じて, 兵食の長期保存方法として開発された一 といら説の真偽はともかく，今をさる170年あまり前の ヨーロッパで，者沸殺菌後の食品をスズめっさした鉄製 製容器につめる方法で世に出たことは成書に記されてい る1。 。それ来, 缶詰はそのすぐれた貯蔵性を生かして まず軍用に普及し，さらには一般の用途にも次第に使わ れるよらになった。

缶用の鉄鋼材料としては，120年以上にわたって主役 の座にあった熱せきブリキに代わって1930年代に電気め っきブリキが欧米で開発され，1955年には日本にもその 技術が導入された。さらに1960年代には，金属クロムと 水和酸化クロムの 2 層から成るティンフリースチール (以下TFS と略す)が日本で開発されて世界に広まった。

これらの新しい展開は, 経済的には, 缶の大量消費時 代をむかえて，より安価な缶用材料を供給しようとする 動きであり，製缶技術の進歩とあいまってはじめて効果 を発揮した。例えばブリキのスズ付着量は, 初期の缶に 用いられていた熱せき材では約 $100 \mathrm{~g} / \mathrm{m}^{2}$ であったが， 技術の向上とともに $17 \mathrm{~g} / \mathrm{m}^{2}$ 程度まで減少し2)，次いで 電気めっき材では $11 \mathrm{~g} \sim 2.8 \mathrm{~g} / \mathrm{m}^{2}$ が一般的となった。 第 2 次大戦後のスズ資源减少による一層の価格高騰は, 一方ではスズを使用しないTFSを生み，他方では，例 えば $1 \mathrm{~g} / \mathrm{m}^{2}$ 以下という少ないスズ付着量からなる薄ス ズめっき鋼板 (Lightly Tin-coated Steel : 以下 LTS と 略す）の誕生を促した。そしてこれらの新材料は, TFSはナイロン系接着剤による接着缶技術，LTSはは んだ缶に代わる Soudronic プロセス等の溶接缶技術と いら関連分野技術の開発・進歩にそれぞれ支えられ，ま た飲料缶の増加（今や食品缶詰の $80 \%$ 以上を占める）と いら最近のすう勢にも助けられて急速に普及し, 在来の ブリキにとって代わろらとしている。

* 川崎製鉄鉄鋼研究所（干260 千葉県千葉市川崎町1） Iron \& Steel Res. Lab. Kawasaki Steel Co. (1 Kawasakicho, Chiba-shi, Chiba 260)
一方，従来からブリキを多用していた食肉や魚を内容 物とする食午の分野では，一層すぐれたブリキが求めら れるよらになった。耐硫化黒变性の向上である。

缶用鋼板の品質特性は, $1 \mu$ 以下といら薄い表面層の 特性によって決定されるため, その開発・改良は, 最近 進歩の著しい表面分析機器の恩恵によるところが非常に 大きい。本稿では，上記のような缶用材料に対する新し いニーズを満たす製品を開発する過程で，これらの表面 分析の手法がいかに役立ったかに焦点をあてて，我々の グループで最近開発し話題となった 3 種類の製品の例を 紹介する。

\section{Ni 拡散処理法による溶接缶用 LTS}

缶胴接合法がはんだづけから抵抗溶接法に変わること により，今まではんだの濡れ性確保のために必要とされ ていた $1 \mathrm{~g} / \mathrm{m}^{2}$ 以上の表面金属スズが不要になった。お゙ りしも塗料の発達により,ブリキ缶のほとんどは塗装し て用いられるよらになり，缶の耐食性維持に果たすスズ の役割は減少した。このような技術的背景の中で低価格 の缶用材料としてLTS が出現したが，初期のそれは， 単にスズめっき付着量を従来の $2.8 \mathrm{~g} / \mathrm{m}^{2}$ (\#25ブリキ) から $1 \mathrm{~g} / \mathrm{m}^{2}$ 以下に減らすものであったため, 耐食性が 劣り, 溶接性も満足のいくものではなく，広く用いられ るには至らなかった。

予備実験の結果，すぐれた溶接性を得るためには，製 缶メーカーでの塗装・焼付後の段階（すなわち, 溶接直 前の状態）で $0.1 \mathrm{~g} / \mathrm{m}^{2}$ 以上の表面金属スズが存在する 必要があること, スズ付着量の減少に伴ら耐食性减少を 補うため, 在来のブリキにない新しい工夫が必要である こと等がわかった。

そこで，高耐食性ブリキの製造法として先に開発した 鋼板表面に $\mathrm{Ni}$ 拡散層を形成させる方法 ${ }^{3}$ （以下 $\mathrm{Ni}$ 払 散処理法と称す）により，原板执よび $\mathrm{Fe}-\mathrm{Sn}$ 系合金層 の電気化学的特性を改善し,さらにブリキと TFS の塗 料密着性の差にヒントを得て, 金属クロムと水和酸化ク ロムからなる皮膜を付与して耐食性を向上させることを 試みた。 


\begin{tabular}{|c|c|c|c|}
\hline \multirow[b]{2}{*}{ 冷間圧延 } & 連続焼鈍ライン & & スズめっきライン(ETL) \\
\hline & 个 $\mathrm{Ni}$ めっ $\rightarrow$ 焼鈍 & 調質圧延 & Snめっき $\rightarrow$ リフローークロメート処理 \\
\hline & $0.04 \sim 0.1 \mathrm{~g} / \mathrm{m}^{2}$ & & 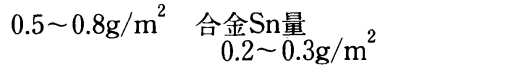 \\
\hline
\end{tabular}

図1 Ni 系LTS の試料調製方法

\section{2-1 供試試料調製と試験方法}

試料調製法を図 1 に示す。冷延鋼板を連続焼鈍ライン に颃いて電解脱脂後 Ni めっきし, ひきつづき HN (7\% $\mathrm{H}_{2}+93 \% \mathrm{~N}_{2}$ ) ガス雲囲気中 $700^{\circ} \mathrm{C}$ で 30 秒間焼鈍し, 鋼板 表面に Ni 払散層を形成させた。調質圧延後, スズめっ きライン（以下ETL と称す）で電解脱脂, 硫酸酸洗拉 よびハロゲン浴でスズめっきを行い，ひきつづきリフロ 一処理によりスズ層を溶融して，スズ換算で $0.2 \sim 0.3$ $\mathrm{g} / \mathrm{m}^{2}$ の $\mathrm{Fe}-\mathrm{Sn}$ 系合金層を形成させてから， $\mathrm{CrO}_{3}$ 系水 溶液中で陰極処理を施した。

こうして得られた供試試料（以下 $\mathrm{Ni}$ 系LTS と称 す）の表面構造は，地鉄側から, Ni めっき後の連続焼 鈍で形成された $\mathrm{Ni}$ 払散層 ( $\mathrm{Fe}-\mathrm{Ni}$ 合金層), リフロー処 理で形成される $\mathrm{Fe}(\mathrm{Ni})-\mathrm{Sn}$ 合金層, 金属スズ層, 金属 クロムと水和酸化クロムから成る特殊クロメート層から なる。

品質特性試験法の概要は以下のようである。

表面抵抗：実際の塗装・焼付条件と等価な $210^{\circ} \mathrm{C} \times 20$ 分の熱処理後の試験片について SQメータ4) で測定した。

溶接適正電流範囲：富士工業侏製 F X400（溶接速度 $40 \mathrm{~m} /$ 分, オーバーラップ幅 $0.3 \sim 0.5 \mathrm{~mm}$, 溶接加圧力
$40 \mathrm{~kg}$ ）を用い，塗装・焼付相当の熱処理後の試験片を 用いて, 上限はスプラッシュ発生電流值, 下限は溶接強 度が十分得られる電流值として求めた。

乾湿くり返し試験：無塗装の試片を, 乾燥状態(温度 $25^{\circ} \mathrm{C}$, 相対湿度 $50 \%$ ) と湿潤状態（温度 $50^{\circ} \mathrm{C}$, 相対湿度 $98 \%$ ）に30分毎にさらし，96時間後の発錆状況を観察し た。

耐ブリスター試験：エポキシフェノール系塗料を 50 $\mathrm{mg} / \mathrm{dm}^{2}$ 塗装した試験片 $(40 \times 80 \mathrm{~mm})$ の下半分を煮沸 した市販のトマトジュースに浸せきし, 密閉した後 $55^{\circ} \mathrm{C}$ で18日間保存して, 試験液浸せき部と非浸せき部とのブ リスター発生状況を観察した。

UCC テスト：上記と同じく塗装した試験片に鋭利な ナイフでクロスカットを入れ， $\mathrm{N}_{2}$ を用いて脱気した 1.5 $\%$ \%エン酸水溶液と $1.5 \%$ 食塩水を $1 ： 1$ に混合した試 験液に浸せきし， $25^{\circ} \mathrm{C}$ で96時間保持した後，クロスカッ トからの塗膜のはく離幅を調べた5)。

孔食試験：塗装した試験片に $30 \mathrm{~mm}$ のスクラッチを 入れ, $10 \%$ 砂糖 $+0.1 \%$ リン酸水溶液 $25 \mathrm{ml}$ 中に $\mathrm{N}_{2}$ 脱 気下で $23{ }^{\circ} \mathrm{C} 2$ 週間放置後, 溶出した鉄量を定量分析す る。

表 1 供試試料の皮膜構成

\begin{tabular}{|c|c|c|c|c|c|}
\hline 試料名 成分 & $\mathrm{Ni}$ 付着量 & $\begin{array}{l}\text { 合金スズ量 } \\
\text { (Sn として) }\end{array}$ & 金属スズ量 & 金属クロム量 & $\begin{array}{c}\text { 水和酸化クロム量 } \\
(\mathrm{Cr} \text { として) }\end{array}$ \\
\hline $\mathrm{Ni}$ 系 LTS & $0.07 \mathrm{~g} / \mathrm{m}^{2}$ & $0.3 \mathrm{~g} / \mathrm{m}^{2}$ & $0.4 \mathrm{~g} / \mathrm{m}^{2}$ & $5 \mathrm{mg} / \mathrm{m}^{2}$ & $10 \mathrm{mg} / \mathrm{m}^{2}$ \\
\hline 怔25ブリキ & - & $0.6 \mathrm{~g}$ & $2.2 \mathrm{~g}$ & $<1 \mathrm{mg}$ & $5 \mathrm{mg}$ \\
\hline \#10ブリキ & - & $0.5 \mathrm{~g}$ & $0.6 \mathrm{~g}$ & $<1 \mathrm{mg}$ & $5 \mathrm{mg}$ \\
\hline $\mathrm{T} \quad \mathrm{F} \quad \mathrm{S}$ & - & - & - & $110 \mathrm{mg}$ & $15 \mathrm{mg}$ \\
\hline
\end{tabular}

表 2 供試試料の品質特性

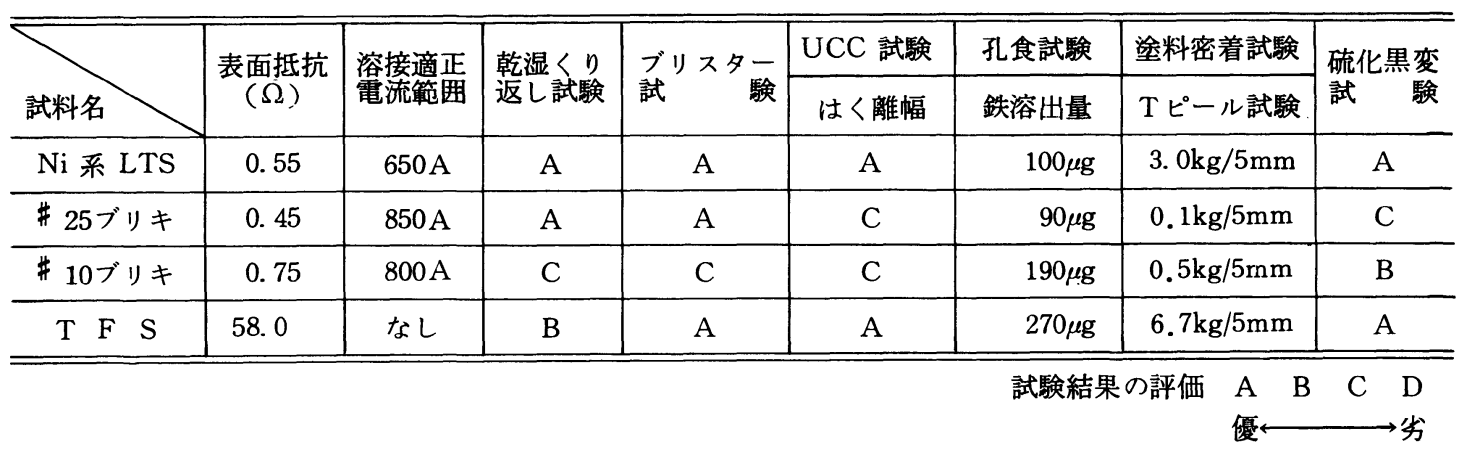


Tピール試験：塗装した試験片を $5 \mathrm{~mm}$ 幅に切断し， 試片 2 枚をナイロンフ、ィルムで加熱区着後, $200 \mathrm{~mm} /$ 分 で引張り，はく離強度を測定する。

硫化黒変試験：塗装した試験片をエリクセン試験機で $5 \mathrm{~mm}$ 押し出し加工後, $1 \% \mathrm{Na}_{2} \mathrm{~S}$ を乳酸で $\mathrm{pH} 7$ 調整 した液に $110^{\circ} \mathrm{C} \times 60$ 分浸せさし，黒変程度を目視判定す る。

\section{2-2 結果と考萛}

実験に用いた試料の皮膜構成および品質特性の概要を， \#25ブリキ，\#10ブリキ，TFSのそれとともに表 $1 ， 2$ にそれぞれ示す。Ni 系LTS は\# 7 相当の薄いスズ付着 量にもかかわらず,すぐれた耐食性, 溶接珄を有するこ とがわかる。

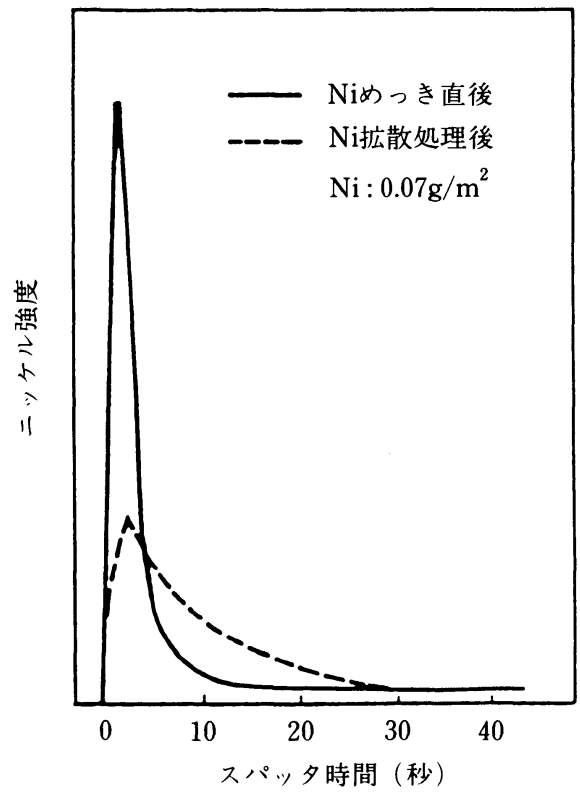

（A） GDSによるNi拡散処理前後の Ni濃度の深さ 方向分布

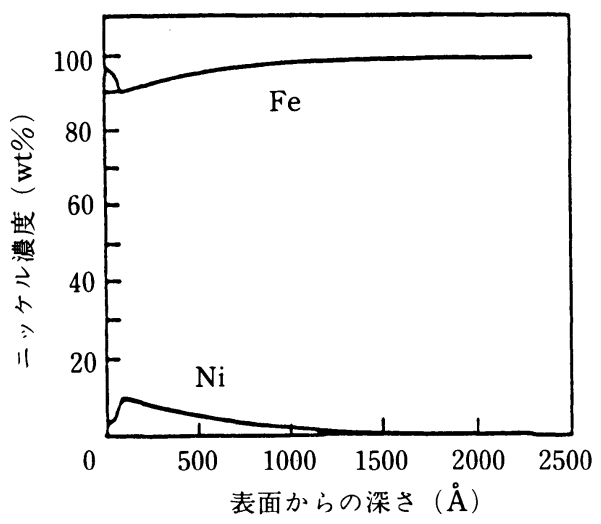

(B) IMMAによる Ni拡散処理鋼板の Ni濃度の深さ 方向分布

図 $2 \mathrm{Ni}$ 拡散処理鋼板の $\mathrm{Ni}$ 濃度の深さ方向分布
$\mathrm{Ni}$ 系 LTSにおける Ni 拡散処理は, 缶の内外面いず れの腐食環境に対しても，表面層の耐食性を向上させる 効果をもつ。図 2 (A)に，Ni めっきした鋼板の払散処 理前後の Ni の深さ方向分布をグロー放電分光分析 (GDS) により調べた結果の一例を示す。また，表面 $\mathrm{Ni}$ 濃度分布決定のために，特に連続焼鈍後の鋼板について 行ったイオンマスマイクロアナライザー (IMMA)によ る深さ方向分布測定結果を，図 2 (B)に示す。Ni めっ き後の熱処理により, $\mathrm{Ni}$ は鋼板中に拡散し $\mathrm{Fe}-\mathrm{Ni}$ 合金 層を形成している。Ni 濃度が最表面ではなく約 $100 \AA$ 内層で最大を示すのは，表面に鉄酸化物が形成している ためと考えられる。以下では便宜上, 払散層の $\mathrm{Ni}$ 濃度 はこの $100 \AA ̊$ 深さの値で表す。

图 3 に曝気した $3 \%$ 食塩水中で測定したスズ，ニッケ ル，通常の鋼板および $\mathrm{Ni}$ 拡散処理した鋼板の腐食電位 を示す。通常の鋼板はスズに対して約 $130 \mathrm{mV}$ 卑であり， スズと局部電池をつくると，鉄はアノードとなって溶解 が促進される。Ni 払散処理により鋼板の電位は高くな ってスズとの電位差は約 $10 \mathrm{mV}$ と小さくなり，大気中 の環境 (缶の外側) では電位差腐食を生じにくくなる。

一方，缶の内側を想定した，酸性果実（グレープフル ーツ) ジュース中での Fe (Ni)-Sn 合金層とスズおよび 鋼板とスズとのカップル電流值である ATC 值 (Alloy Tin Couple Current Value) ${ }^{6}$ および STC 值 (Steel Tin Couple Current Velue)は，図4に示したように，いず れも $\mathrm{Ni}$ めっき量が増すにつれて低下しており， Fe ( Ni) -Sn 合金層および地鉄の電気化学的特性が改善され，ア ノードであるスズとカソードとなる合金層および地鉄の 間のカップル電流が小さくなって，耐食性が向上してい ることがわかる。

ブリキの耐食性は Fe-Sn 系合金層が緻密なほどすぐ れているが, Ni 系LTS では，扗散層中の Ni 濃度が増

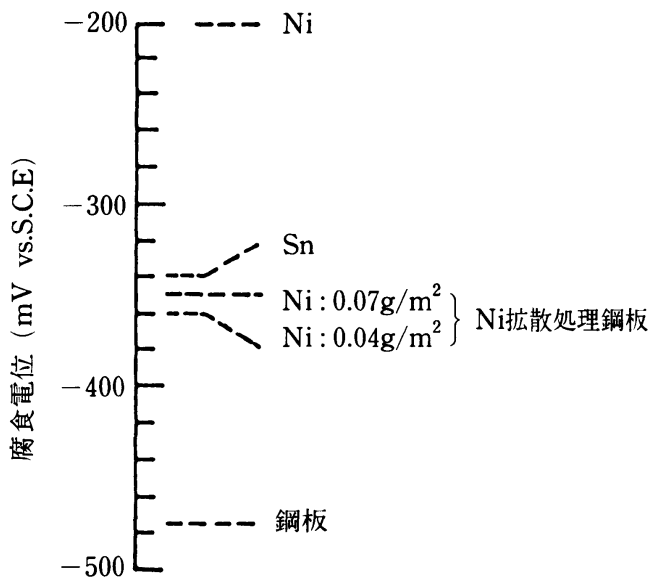

図 3 $3 \%$ 食塩水溶液中に打ける金属スズ，金属ニッケル板お よび Ni 拡散処理鋼板の腐食電位 


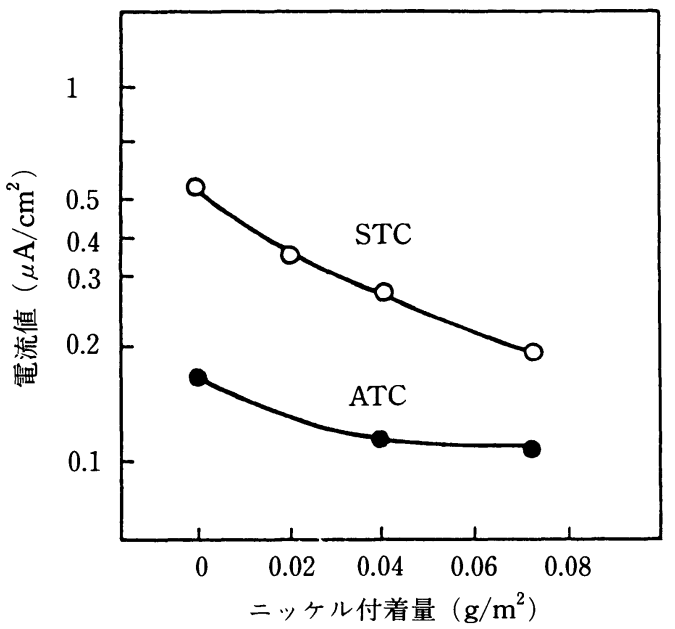

図4 $\mathrm{Ni}$ 系LTS の ATC 值扣よび STC 值に及ほす $\mathrm{Ni}$ 付着量 の影響

大するにつれてリフロー処理によって形成する合金層は 緻密となり，特に $5 \%$ 以上になると鋼板表面をよく被覆 する。化学分析とX線回折の結果では，Ni 系 LTS の合 金層の結晶構造は $\mathrm{FeSn}_{2}$ と同形で, $\mathrm{Ni}$ が $\mathrm{Fe}$ 格子点の 一部を膡換した $\mathrm{Fe}(\mathrm{Ni})-\mathrm{Sn}$ 合金となっている。ATC 値が低かったのは，この緻密な合金形成による。

ブリキでは塗装・焼付時にスズの合金化が起こり，金 属スズが減少する。前述のように，溶接時に $0.1 \mathrm{~g} / \mathrm{m}^{2}$ の金属スズが存在すれば満足な溶接性が得られるが，め っき原板の表面 Ni 濃度が高いとスズの合金化を促進し， 残存金属スズ量が減少して溶接劣化に至る。Ni めっき 量, 払散処理の程度を変えた試料を調製し, IMMA で 求めた $\mathrm{Ni}$ 払散層中の $\mathrm{Ni}$ 濃度と塗装・焼付後に残る金 属スズ量との関係を調べた（図 5 ）。溶接性の観点から は, $\mathrm{Ni}$ 払散層中の $\mathrm{Ni}$ 濃度は $30 \%$ 以下にする必要のある ことがわかった。

以上の結果から, $\mathrm{Ni}$ 払散層中の $\mathrm{Ni}$ 濃度を $5 \sim 30 \%$ に 保つことによって，耐食性・溶接性ともにすぐれた $\mathrm{Ni}$ 系 LTS が生産されている7) 9)。

\section{3. 逆電解法によるレトルト缶用 TFS}

TFS とはスズのついていない表面処理鋼板の意味で あるが，現在では，下層が $100 \mathrm{mg} / \mathrm{m}^{2}$ 程度の金属ク口 么，上層が $10 \sim 25 \mathrm{mg} / \mathrm{m}^{2}$ (Cr 量として) の水和酸化ク ロムからなる薄い皮膜で被覆された鋼板をさす。

TFS はブリキと比較して塗料との密着性がよく，こ の長所を生かしてナイロン系接着剤による製缶法が開発 され，まず低温殺菌されるビール缶，炭酸领料缶などに 利用されて使用量が増大した。その後塗料密着珄の向上 がはかられて，昭和51年頃にはホットハックされる果汁 飲料缶にも適用され，さらに昭和 53 年には $100{ }^{\circ} \mathrm{C}$ 以上で

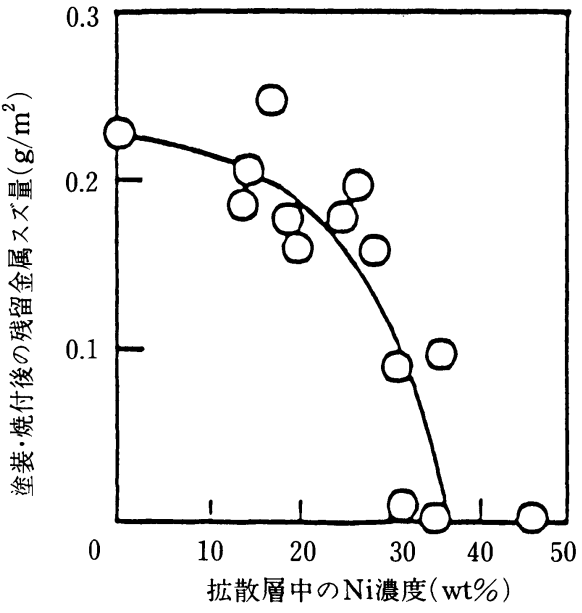

図 $5 \mathrm{Ni}$ 払散層の $\mathrm{Ni}$ 濃度と塗装・焼付後の金属残留スズ量と の関係

加熱殺菌処理（レトルト処理）されるコーヒ一飲料なと のレトルト缶としても利用されはじめた。

開発初期の TFS は，塗料密着性はブリキよりすぐれ ていたが，加熱殺菌時拉よびその後長期間応力下で保存 された場合の，いわゆる塗料 2 次密着性は十分でなかっ た。TFS の表面皮膜の厚みは金属ク口ム, 水和酸化ク ロムあわせても $300 \sim 400 \AA$ と薄く，塗料との密着性を 調べるにはその最表面が重要なことから，特に上層の水 和酸化ク口ム膜についてオージェ電子分光分析法 (AES)，X線光電子分光分析法 (ESCA) などにより詳 細な検討が行われた。その結果，塗料 2 次密着性は水和 酸化クロムの主成分である $\mathrm{Cr}, \mathrm{O}, \mathrm{H}$ の結合状態に左右さ れるが，特にめっき時に処理浴に添加されていた $\mathrm{SO}_{4}{ }^{2-}$ は著しく塗料 2 次密着性を低下させることが知られた ${ }^{10}$ $\sim 12)$ 。

硫酸根に代表される耐レトルト性に有害なアニオンを 水和酸化ク口ム膜から抽出するための種々の方法を予備 的に検討した結果，鋼板を陽極として電解処理を施すと 速やかに目的を達することを見いだし，次のような実験 を行った。

\section{3-1 供試試料調製と試験方法}

常法により脱脂・酸洗した鋼板を，まず $\mathrm{CrO}_{3}-\mathrm{H}_{2} \mathrm{SO}_{4}$ $-\mathrm{Na}_{2} \mathrm{SiF}_{6}$ 浴中で陰極処理（クロムめっき）し，ひきつ づき同浴中で陽極処理（逆電解）を行った後，不純物之 してしかアニオンを含まない $\mathrm{CrO}_{3}$ 浴中で陰極処理（電 解ク口ム酸処理）し，金属ク口ム付着量 $90 \sim 110 \mathrm{mg}$ / $\mathrm{m}^{2}$, 水和酸化クロム量 $15 \sim 20 \mathrm{mg} / \mathrm{m}^{2}(\mathrm{Cr}$ として) にな るように調整した。

品質特性試験法の概要は以下のようである。 水和酸化クロム膜の均一性：光学顕微鏡観察による。 塗料 2 次密着性：2-1項と同様にして作製した $5 \mathrm{~mm}$ 
表 3 供試試料の表面特性と性能

\begin{tabular}{|c|c|c|c|c|c|c|c|c|}
\hline \multirow{3}{*}{$\begin{array}{l}\text { 試 } \\
\text { 料 } \\
\text { 名 }\end{array}$} & \multicolumn{3}{|c|}{ 試料調製プロセス } & \multicolumn{5}{|c|}{ 表 面 } \\
\hline & \multicolumn{2}{|c|}{$\begin{array}{l}\text { クロムめっき } \\
\text { エ 程 }\end{array}$} & \multirow{2}{*}{ 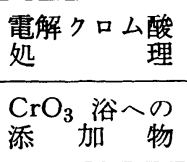 } & \multirow{2}{*}{$\begin{array}{l}\text { 水和酸化クロム } \\
\text { 皮膜の均一性 }\end{array}$} & \multicolumn{2}{|c|}{$\begin{array}{l}\text { ESCA による表面 } \\
\text { 分析(ピーク高さ比) }\end{array}$} & \multicolumn{2}{|c|}{ 水和酸化クロム皮膜の性能 } \\
\hline & め名台 & $\begin{array}{l}\text { 逆電解 } \\
\text { 処 理 }\end{array}$ & & & $\mathrm{S} / \mathrm{Cr}$ & $\mathrm{F} / \mathrm{Cr}$ & $\begin{array}{l}\text { 塗料二次密着性 } \\
(\mathrm{kg} / 5 \mathrm{~mm})\end{array}$ & $\begin{array}{c}\text { レトルト耐久性 } \\
\text { (分) }\end{array}$ \\
\hline 1 & 実施 & 実施 & 添加せず & 一 & 0.012 & 0.08 & 3. 0 & $>210$ \\
\hline 2 & 実施 & なし & 添加せず & 不均一 & 0.023 & 0.10 & 1.8 & 30 \\
\hline 3 & 実施 & なし & $\mathrm{H}_{2} \mathrm{SO}_{4}$ & 一 & 0.075 & 0.02 & 2. 2 & 60 \\
\hline 4 & 実施 & なし & フッ素化合物 & 均 & 0.010 & 0.22 & 2.5 & 120 \\
\hline
\end{tabular}

幅の塗装後試験片 2 枚をナイロンフィルムで加熱圧着し， $90^{\circ} \mathrm{C} ， 0.4 \%$ クエン酸溶液中に 2 週間浸せきした後， T ピールはく離試験を行う。

レトルト耐久性：上記と同様に塗装・焼付した試験片 2 枚を，ナイロンフィルムをはさみ， $5 \mathrm{~mm}$ 重ね合わせ て加熱圧着して作製したテストピースをU字型に曲げた 状態で $130{ }^{\circ} \mathrm{C}$ のレルト処理を行い，半分以上のテスト ピースがはく離するまでの耐久時間で評価した。

\section{3-2 結果と考察}

クロムめっきと電解クロム酸処理を分離して行ら 2 ス テッププロセスで調製した，各種 TFS の表面特性と性 能とを表 3 に示す。クロムめっき後に逆電解を行い，つ ついて不純物としてしか $\mathrm{SO}_{4}{ }^{2-}, \mathrm{F}^{-}$などのアニオンを含 まない $\mathrm{CrO}_{3}$ 水溶液中で電解クロム酸処理することによ り，共析アニオンの非常に少ない水和酸化クロム皮膜を 均一に形成させることができ，こうして得られた TFS の塗料 2 次密着性は非常にすぐれている（表 3 の試料 No.1)。

逆電解を行わない通常の 2 ステップ法では,アニオン フリーの電解クロム酸浴を用いると共析アニオンの少な い水和酸化クロム膜を得ることができるが，皮膜厚みは

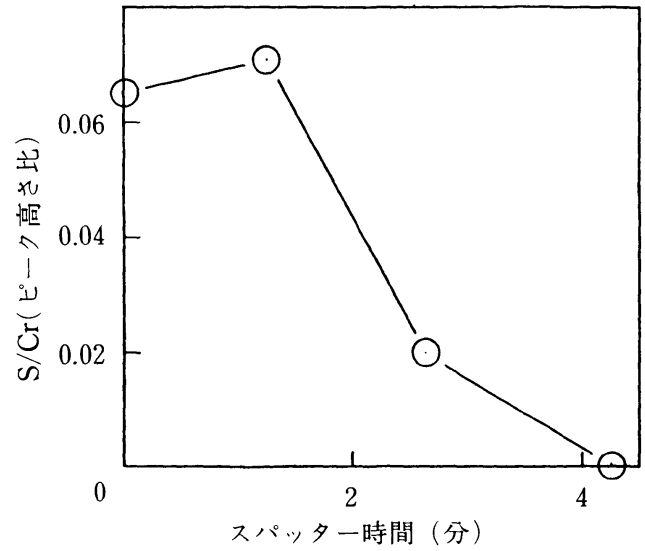

図 6 AES 上るクロムめっき鋼板上の水和酸化クロム皮膜の $\mathrm{S}$ 濃度の深さ方向分布
不均一となり，塗料 2 次密着性は非常に劣る（試料 No.2)。また，アニオンを多量に添加した電解クロム酸 浴を用いると水和酸化ク口ム皮膜の厚みは均一となるが， 膜中への共析アニオンは多くなり, やはり塗料 2 次密着 性は劣る（試料 No.3，4）。膜中への共析アニオンとし ては，硫酸根はフッ素よりもはるかに有害であることも 示された。

逆電解処理の効果・機構を調べるため, 各段階での水 和酸化クロム皮膜について調べた。

クロムめつき後の鋼板表面に存在した水和酸化クロム 皮膜の硫黄濃度の深さ方向分布を，AESで測定した結 果を図 6 に示す。 $\mathrm{S} / \mathrm{Cr}$ 比がゼロとなる深さは，下層の 金属ク口ム層に達した深さと考えられ，この図からク口 ムめっき浴中の硫酸根に由来する S は，水和酸化クロム 皮膜の表面近傍に偏在していることがわかる。

次に, 逆電解法の各工程に沶いて水和酸化クロム皮膜 表面の硫酸根，フッ素含有量がどのように変化するかを ESCA を用いて調べた（图 7 )。ク口ムめっき後に水和 酸化クロム表面層に多量に存在した硫酸根やフッ素イオ

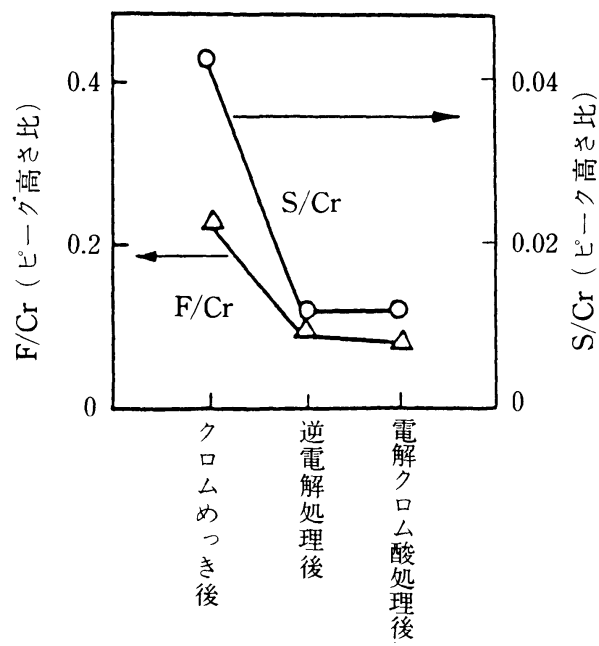

図 7 ESCA による逆電解処理プロセスの各段階に扣ける表 面皮膜中 $\mathrm{S}$ と $\mathrm{F}$ の変化 
ンは逆電解によって減少し, その後の電解クロム酸処理 後も増加しない。その間, 水和酸化クロム皮膜は, クロ ムめっき後の形成量の半分程度は逆電解工程で溶解し, その後の電解クロム酸処理工程で所定付着量に調整され る。

逆電解工程のもら一つの効用は, 水和酸化クロム皮膜 の均一性改善にある。TFS の塗料 2 次密着性を損ら一 因は水和酸化クロム皮膜の不均一さにあることが指摘さ れているが(3), 逆電解処理はクロムめっさ工程で発生し た凹凸のある表面層を溶解し，その後の電解クロム酸処 理工程での均一皮膜形成を助けることが, EPMA によ る表面走査分析の結果知られた。

以上のように，2 ステップ法においてクロムめっき後 に逆電解処理を挿入する逆電解法は,

(1)まず，硫酸根，フッ素イオンを含むめっき浴で鋼板を 陰極処理し, 効率よく金属クロムの必要量を確保し, 次 いで,

(2)同めっき浴中で鋼板を陽極処理して, 凹凸の多い有害 な゙ンオンを多く含んだ水和酸化クロムの表面層を強制 的に溶解除去する。

(3)水洗後, 硫酸・フッ素化合物を添加しない浴中で電解 クロム酸処理を行って所定量の水和酸化クロム皮膜を付 与する。

こらして得られた TFS は, 表層には純度のよい水和 酸化クロム皮膜が均一に形成していて, $\mathrm{SO}_{4}{ }^{2-}, \mathrm{F}^{-}$イオ ン含有量は従来品の $1 / 4$ に減少しており，極めてすぐれ た塗料密着性を有している14) 16)。

\section{4. 耐硫化黒変性ブリキ}

ブリキ缶に魚や食肉のような高たんぱく質含有食品を 充てんした時, 高温殺菌のためのレトルト処理工程で缶 の内面が黒色化してトラブルを起こす。これは, 食品中 の硫黄含有アミノ酸の熱分解によって生成した $\mathrm{H}_{2} \mathrm{~S}$ あ るいは HS-イオンがスズと反応してスズ硫化物を形成 したためで, 硫化黒変とよばれ, 内容物の風味や栄養価 を損うものではないが，消費者からは容認されず，最近 では致命的評価の原因となることもある。

ブリキの硫黄黒変については先人によるすぐれた研究 があり，金属クロムによるスズ表面の被覆が耐硫化黒変 性向上に有効なこと ${ }^{17)}$, 硫化黒変がブリキ表面の $\mathrm{SnO}$ を起点として発生し, $\mathrm{SnO}_{2}$ や水和酸化クロムによるス ズ表面の十分な被覆は硫化黒変抑制に効果があること ${ }^{18)}$ などが報告されている。ここでは，当社で10年以上にわ たって工業的に採用されてきた，クロメート処理前の炭 酸ソーダ中陰極処理のブリキ表面皮膜に及ぼす効果につ いて紹介する。

\section{4-1 供試試料調製}

通常の調質圧延後の鋼板をETL で電解脱脂, 硫酸酸
洗およびスズめっきを行い，ひきつづきリフロー処理し た。次いで $\mathrm{Na}_{2} \mathrm{CO}_{3}$ 水溶液中で陰極処理 $\mathrm{Na}_{2} \mathrm{CO}_{3}$ 処理 と称す）してから， $\mathrm{Na}_{2} \mathrm{Cr}_{2} \mathrm{O}_{7}$ 水溶液中で陰極処理 (CDC 処理と称す) を行った。比較材として $\mathrm{Na}_{2} \mathrm{CO}_{3}$ 処 理を挿入しない在来工程の製品も使用した。

硫化黒変試験は，2-1の方法で行った。

\section{4-2 結果と考察}

硫化黒変試験の結果, 在来の CDC 処理材では平板部, 加工部ともに著しい黒变が認められ，スズの結晶模様も 明確に観察された。一方, $\mathrm{Na}_{2} \mathrm{CO}_{3}$ 処理 $\rightarrow \mathrm{CDC}$ 処理を施 したブリキでは，平板部では黒変は認められず，加工部 の変化も極めて軽微であった。

硫化黒変試験において認められた上記の両サンプルの 耐硫化黒変性の差について検討するため，表面皮膜につ いて調べた。図8 (A) は不働態皮膜を水銀アマルガム法

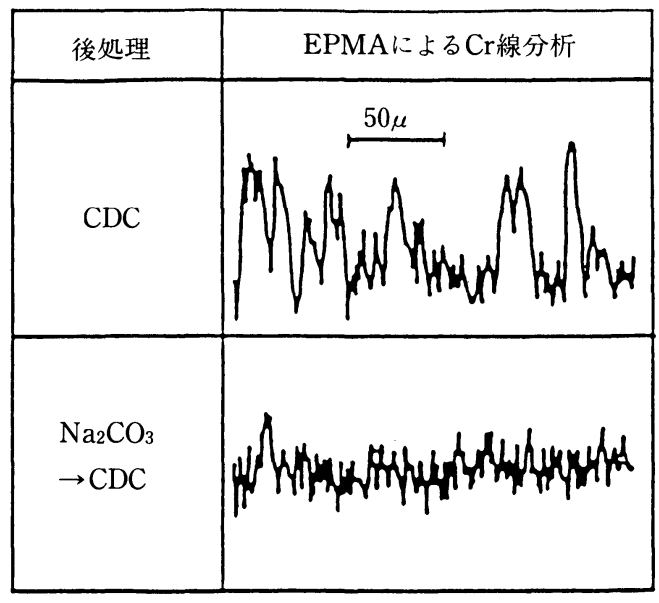

(A)EPMAによるブリキ不働態皮膜中 $\mathrm{Cr}$ の表面分布

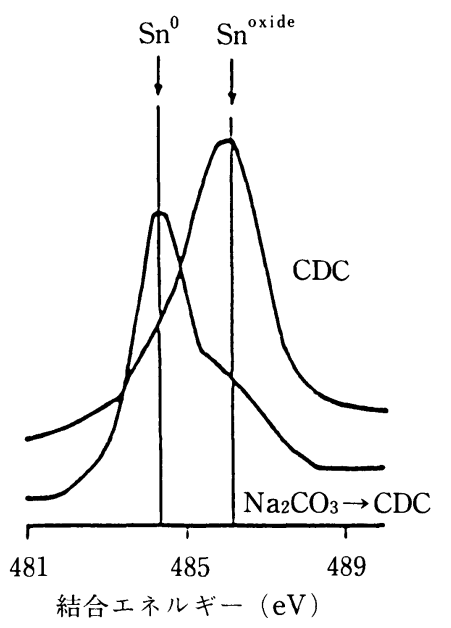

(B) ESCAによるブリキ表面のSn $3 d 5 / 2$ スペクトル

図8 不動態化処理したブリキの表面分析結果 
によりはく離して, EPMA で Cr 線分析を行った結果 である。 $\mathrm{Na}_{2} \mathrm{CO}_{3} \rightarrow \mathrm{CDC}$ 処理材では在来の CDC 処理材 と比べて Cr 分布が均一で，クロメート皮膜がブリキ表 面を均一に被覆していることを示している。図8（B)は， 上記 2 種のブリキ表面の $\operatorname{Sn} 3 \mathrm{~d}_{5 / 2}$ スペクトルであり， 在来の CDC 処理材ではスズ酸化物が主であるが, $\mathrm{Na}_{2}$ $\mathrm{CO}_{3} \rightarrow \mathrm{CDC}$ 処理材ではスズ酸化物は少なく, 金属スズ が主体であることがわかる。以上のことから， $\mathrm{Na}_{2} \mathrm{CO}_{3}$ 処理はリフロー処理時に生成するスズ酸化膜を還元して 表面を均一にし, その後のクロメート処理時にクロメー ト層が均一に表面を被覆することを可能とし, その結果 レトルト処理時の $\mathrm{SnS}$ 生成の起点が減少して硫化黒変 防止に効果を有するものと思われる。

Rocquet ら ${ }^{17)}$ によって提案された金属クロムの付与は もとより硫化黒変防止にも有効であるが，ブリキ表面の はんだ需れ性を劣化させる傾向があり，はんだ缶にはむ かない。それに対して, $\mathrm{Na}_{2} \mathrm{CO}_{3}$ 中の陰極処理と CDC 処理をらまく組み合わせることによって, 缶胴接合, 耐 硫化黒変の両方について良いパフォーマンスが得られる。

\section{5.おわりに}

おるに材料開発を行ら立場から，進歩の著しい ESCA, AES な゙の表面分析機器が最近の缶用材料の開 発にいかに役立ったかについて紹介してきた。缶用材料 は概して $1 \mu$ 以下，場合によっては $0.05 \mu$ 以下という 極薄の表面層（しかも複数の）がその製品特性を決定す る分野であり，その意味では LSI やファインセラミッ クスに代表される最近はやりのハイテクノロジー材料技 術を，はるかに以前から先取りしてきた先進的分野とも いえる。
とはいえ, 技術の進歩は止まる所を知らず，より敩し い使用環境に適応できる高品質の製品を低コストで製造 する技術の必要性は，今後さらに高まろう。その意味で も表面分析，製品開発両分野の一層の共同作業が望まれ る。

\section{文献}

1）日本缶詰協会；缶詰製造講義 I（1960）

2）安藤卓雄；金表誌，35，94（1984）

3）藤巻武俊，四十万小二, 原田俊一；特公昭54-20940

4）松永正久；表面測定・工業技術全書22

5) O.D. Gonzalez, P.H. Josephic and R.A. Orian ; J. Electrochem. Soc., 121, 29 (1974)

6) G.G. Kamm, A.R. Willey, R.E. Beese and J.L. Krickl ; Corrosion, 17, 106 (1961)

7）望月一雄，中小路尚匡，国分淳子，坂本安平，市田敏郎， 入江敏夫；鉄と鋼，69，S 1231 (1983)

8）中小路尚匡, 望月一雄, 国分淳子, 坂本安平, 市田敏郎, 入江敏夫；鉄と鋼，69，S 1232 (1983)

9）中小路䣊匡, 緒方一, 望月一雄, 市田敏郎; 鉄と鋼, 70, S 326 (1984)

10) S. Maeda, T. Asai, H. Omata and H. Okada ; Proc. Interfinish-' 80, p.432 (1980)

11）乾恒夫, 西条謹二, 清水信義; 金表誌，32，80（1981）

12）乾恒夫, 西条謹二, 清水信義; 東洋鋼板, 125, 33（1982）

13）松林宏；金表誌，33，465（1982）

14）緒方一, 小林秀夫, 津川俊一, 山地京子, 市田敏郎, 入江 敏夫；鉄と鋼，69，S 1237 (1983)

15）緒方一, 山地京子, 中小路尚匡, 望月一雄, 市田敏郎; 鉄 之鋼，70，S 319 (1984)

16）緒方一，中小路尚匡，望月一雄，市田敏郎；鉄と鋼， 71, A 85 (1985)

17) P. Rocquet and P. Aubrun ; Br. Corros. J., 5, 193 (1970)

18）乾恒夫，根本忠志，西条謹二，河村宏明；鉄と鋼，68， 850 (1982) 